\title{
Posner on Vertical Restraints
}

\author{
C. Scott Hemphill†
}

\section{INTRODUCTION}

This Essay considers the influence of Richard Posner's judicial opinions about antitrust law. In thirty-six years on the bench, Posner wrote about one antitrust opinion per year, which represents roughly 1 percent of his judicial output. The opinions address a wide range of conduct, from restraints of trade to monopolization to mergers, plus such related issues as antitrust injury, standing, and damages. Posner's antitrust opinions are frequently cited by courts and commentators, and many of the citations are branded with a "Posner, J." parenthetical. ${ }^{1}$

I do not attempt a comprehensive account of Posner's extraordinary influence as a judge. There is too much ground to cover; indeed, his importance to antitrust law alone has been the subject of a recent symposium. ${ }^{2}$ Instead, I focus on a single category of conduct: vertical restraints on distribution, such as resale price maintenance (RPM), maximum RPM, and exclusive sales territories. Posner, together with other members of the Chicago School, sought to shift the rule governing these restraints from a flat (per se) prohibition to a more relaxed or nuanced evaluation.

The law of vertical restraints was indeed transformed over the course of Posner's long engagement with antitrust law. Three strategies were important in this effort. First, and most obvious, Posner deployed economic reasoning to justify more lenient

$\dagger$ Professor of Law, New York University School of Law. I thank Harry First, Eleanor Fox, Bert Huang, Jon Jacobson, Saul Levmore, and Tim Wu for helpful comments. Alex Gelb, Tim Keegan, Alison Perry, and Phantila Phataraprasit provided outstanding research assistance.

1 For an early analysis of citations as a measure of judicial influence, see Richard A. Posner, Cardozo: A Study in Reputation 69-73 (Chicago 1990). See also Stephen J. Choi and G. Mitu Gulati, Mr. Justice Posner? Unpacking the Statistics, 61 NYU Annual Survey Am Law 19, 28 (2005) (documenting the frequency of citations of Posner's opinions between 1998 and 2000).

2 See generally the recent collection in the Antitrust Source, with contributions by Rebecca Haw Allensworth, Eleanor Fox, Doug Ginsburg, Keith Hylton, and Steve Salop. Symposium: Judge Posner Retrospective, 18 Antitrust Source 1 (Oct 2018). 
treatment. Once that began to work, and some but not all restraints were subject to lenient treatment, a second strategy kicked in: to criticize the inconsistencies and press for their harmonization.

Third, Posner opened up an indirect line of attack by shifting attention from the question of antitrust liability to the question of antitrust injury - whether a plaintiff has suffered an injury of the type the antitrust laws were intended to prevent. Even if a plaintiff shows an antitrust violation, there might be no antitrust injury because the plaintiff's claimed harm is economically incoherent or results from more competition, rather than less. Antitrust injury provided the means to sidestep and undermine Supreme Court precedent that Posner disagreed with but could not ignore.

Posner's influence as a judge is impossible to isolate from his impact as a leading antitrust scholar, in part because his opinions often have drawn on arguments that he first made as an academic. In vertical restraints, the interaction of judicial and academic influence is particularly pronounced. Accordingly, I also discuss Posner's academic work as it fueled and intersected with his judicial output.

This Essay proceeds in four parts. Part I describes Posner's successful academic critique of per se liability, which emphasized the benign effects of various vertical restraints and pressed for consistent treatment among them. Part II explains how Posner, in one of his first antitrust cases as a judge, adapted this critique to the evaluation of maximum RPM. Here, Posner's conclusion that maximum RPM plaintiffs suffered no antitrust injury not only offered a new avenue to criticize per se liability on economic grounds but also set up a new source of inconsistency, this time between the narrow scope of recovery and broad scope of liability. Part III considers the use of antitrust injury and analogous doctrines as a weapon to undermine other broad impositions of liability in antitrust law and beyond.

Part IV turns to horizontal restraints, a second area of antitrust law in which one might have expected Posner's distinctive scholarship to leave a strong imprint on his work as a judge. Here, however, Posner did little to convert his academic ideas about horizontal restraints into law and ultimately became their fiercest judicial critic. In one of his last antitrust opinions, Posner shaped Seventh Circuit doctrine to expressly reject one of his signature academic positions. The contrast to vertical restraints, 
an area in which Posner pressed hard to incorporate his academic views into antitrust law, is stark.

\section{The ACADEMiC CRITIQUe OF PER SE Liability}

Vertical intrabrand restraints place restrictions on how a dealer sells the manufacturer's product and at what price. For example, RPM requires a retailer to sell a product at or above a minimum price set by the manufacturer. Maximum RPM is the flip side of minimum RPM. It places a ceiling rather than a floor on the retailer's price. Nonprice restraints, such as exclusive sales territories, have broadly similar effects to RPM.

In 1969, when Posner joined the Chicago faculty, all three types of restraint-RPM, maximum RPM, and nonprice restraints-were unlawful per se. ${ }^{3}$ The Supreme Court subsequently shifted the law from per se illegality to the more lenient rule of reason in a series of cases decided over a period of thirty years. ${ }^{4}$ The rule of reason requires a plaintiff to demonstrate anticompetitive effects and invites an analysis of procompetitive justifications and market power. This sea change is widely attributed to a sustained critique of per se liability by Chicago School thinkers, supported by the judicial opinions of Chicago School judges. ${ }^{5}$

Posner's influence on vertical restraint law arose first as an academic member of the Chicago School, whose other prominent members included future judges Robert Bork and Frank Easterbrook. Posner's initial critique of vertical restraints doctrine was published in 1975 and incorporated in a book published the following year. ${ }^{6}$ A major target was the Court's opinion in United

3 See Dr. Miles Medical Co v John D. Park \& Sons Co, 220 US 373, 409 (1911) (RPM); Albrecht $v$ Herald Co, 390 US 145, 152-53 (1968) (maximum RPM); United States v Arnold, Schwinn \& Co, 388 US 365, 382 (1967) (nonprice restraints).

4 See Continental T.V., Inc v GTE Sylvania Inc, 433 US 36, 58 (1977) (overruling Schwinn); State Oil Co v Khan, 522 US 3, 7 (1997) (overruling Albrecht); Leegin Creative Leather Products, Inc v PSKS, Inc, 551 US 877, 907 (2007) (overruling Dr. Miles).

5 See generally Daniel A. Crane, Book Review, Chicago, Post-Chicago, and NeoChicago, 76 U Chi L Rev 1911 (2009) (assessing the influence of the Chicago School on antitrust doctrine)

6 See generally Richard A. Posner, Antitrust Policy and the Supreme Court: An Analysis of the Restricted Distribution, Horizontal Merger and Potential Competition Decisions, 75 Colum L Rev 282 (1975). See also Richard A. Posner, Antitrust Law: An Economic Perspective 147-66 (Chicago 1976). Antitrust Law was Posner's third book, following Economic Analysis of Law (Little, Brown 1973) and Antitrust: Cases, Economic Notes, and Other Materials (West 1974). 
States $v$ Arnold, Schwinn, \& Co, ${ }^{7}$ which had imposed per se liability for nonprice restraints. ${ }^{8}$ Posner was unusually well positioned to criticize Schwinn, having briefed and argued (and won) the case as a young lawyer in the Solicitor General's office. The critique thus represented, as he candidly wrote, a "180-degree turn."9

Posner argued that, as an economic matter, nonprice restraints generally lack any anticompetitive effect and often enhance interbrand competition between manufacturers. This approach was, of course, a version of the first strategy discussed above. For example, an exclusive sales territory may promote competition by solving a free rider problem among retailers in the provision of point-of-sale services valued by consumers. ${ }^{10}$ Meanwhile, a particular restraint might be harmless from the standpoint of intrabrand competition given the manufacturer's strong desire to promote retailer competition and thereby minimize retailer margins. ${ }^{11}$ Posner advocated lenient treatment for RPM along the same lines. ${ }^{12}$

Posner's scholarship soon caught the attention of the Supreme Court. In 1977, the Court overruled Schwinn, holding in Continental T.V., Inc $v$ GTE Sylvania Inc ${ }^{13}$ that nonprice restraints are subject to the rule of reason. ${ }^{14}$ The Court's opinion cited Posner extensively (alongside other academics), noting his account of the manufacturer's free rider problem ${ }^{15}$ and its interest in preserving intrabrand competition. ${ }^{16}$ Beyond the specific analysis of nonprice restraints, the Court's opinion was notable

7388 US 365 (1967).

8 Id at 382 .

9 Richard A. Posner, The Rule of Reason and the Economic Approach: Reflections on the Sylvania Decision, 45 U Chi L Rev 1, 2 (1977) (describing the position taken in Posner, 75 Colum L Rev at 282 (cited in note 6)).

10 Posner, 75 Colum L Rev at 283-84 (cited in note 6), citing Lester G. Telser, Why Should Manufacturers Want Fair Trade?, 3 J L \& Econ 86 (1960). Posner argued that this benefit is particularly important to manufacturers that are trying to enter the market or expand. Posner, 75 Colum L Rev at 293 (cited in note 6).

11 Posner, 75 Colum L Rev at 283, 287-88 (cited in note 6).

12 As discussed in Part II, the effects of maximum RPM are different.

13433 US 36 (1977).

14 Id at 58.

15 See id at 55; Posner, 75 Colum L Rev at 285 (cited in note 6).

16 See Sylvania, 433 US at 56 n 24 (manufacturer's interest in minimizing retailer margins), citing Posner, 75 Colum L Rev at 283 (cited in note 6); Sylvania, 433 US at 56 (manufacturer's interest in intrabrand competition), citing Posner, 75 Colum L Rev at 283, 287-88 (cited in note 6). Posner's comments about entry and expansion were picked up by a concurring opinion. See Sylvania, 433 US at $65 \&$ n 7 (White concurring in the judgment), citing Posner, 75 Colum L Rev at 293 (cited in note 6). 
for its emphasis on economic analysis. ${ }^{17}$ This emphasis was amplified by the Court's repeated citation of Posner and other economically minded scholars and its acknowledgment of heavy academic criticism of the Schwinn rule. ${ }^{18}$

Posner's academic work also identified inconsistencies and pressed for their harmonization, a version of the second strategy. Nonprice restraints and RPM have similar economic effects. Among other similarities, both can support interbrand competition. Posner's pre-Sylvania paper had argued that nonprice restraints and RPM therefore should be treated similarly-that is, leniently_given their similar economic effects. ${ }^{19}$ Justice Byron White, writing separately in Sylvania and anticipating the slippery slope, acknowledged the force of this point as a reason to resist an economic approach to vertical restraints. ${ }^{20}$ In a second paper published a few months after Sylvania, Posner emphasized the inconsistency that Sylvania had opened up between nonprice restraints (rule of reason) and RPM (per se illegal). ${ }^{21}$ He pointed to the Sylvania Court's emphasis on free riding and interbrand competition as a reason to get rid of per se liability for RPM and maximum RPM, describing the latter as an "endangered" precedent. ${ }^{22}$

Posner spotted a further discrepancy arising from Sylvania, between nonprice restraints and maximum RPM. Maximum RPM is useful as a way to rein in exploitation of market power by a dealer, including market power arising from the grant of exclusive sales territories. On the one hand, Sylvania permitted some exclusive sales territories under the rule of reason. Yet the Supreme Court's decision in Albrecht $v$ Herald $\mathrm{Co}^{23}$ flatly prohibited the use of maximum RPM, despite its usefulness in conjunction with those sales territories. Posner exploited the resulting tension, pointing to the facts of Albrecht itself:

17 See Sylvania, 433 US at 53 n 21 ("Competitive economies have social and political as well as economic advantages, ... but an antitrust policy divorced from market considerations would lack any objective benchmarks.").

18 See id at 47-48 \& n 13, citing generally Posner, 75 Colum L Rev 282 (cited in note 6 ), among others.

19 Posner, 75 Colum L Rev at 298 (cited in note 6) (advocating consistently lenient treatment for both types of restraint). Posner further argued that restraints achieved through agency rather than sales contracts should be treated the same. Id.

20 Sylvania, 433 US at 70 (White concurring in the judgment), citing Posner, 75 Colum L Rev at 298 (cited in note 6).

21 Posner, 45 U Chi L Rev at 7-9 (cited in note 9).

22 Id at 10

23390 US 145 (1968). 
Because the publisher [in Albrecht] had assigned the distributors exclusive territories, the most likely reason for the price ceiling was to prevent the distributor from using his distribution monopoly for his benefit rather than the publisher's. The logic of Sylvania is that restrictions imposed on dealers by manufacturers promote interbrand competition and are therefore not per se illegal, save perhaps if the manufacturer has a monopoly. That logic demolishes Albrecht. ${ }^{24}$

The implication was that Albrecht was wrongly decided, at least when maximum RPM was used for this purpose.

\section{ANTITRUST INJURY AND MAXIMUM RPM}

In 1981, when Posner joined the Seventh Circuit, the evolution in vertical restraints doctrine was well underway. As a judge, Posner soon had an opportunity to put his academic critiques to practical use. ${ }^{25}$ In 1984, his court took up Jack Walters \& Sons Corp $v$ Morton Building, Inc, ${ }^{26}$ a maximum RPM claim squarely within the Albrecht rule. ${ }^{27}$

Posner's opinion rejecting the antitrust claim criticized both the economic reasoning underlying Albrecht and its fit with other cases. The opinion explained, relying on Easterbrook's academic work, that maximum RPM tends to force prices down toward the competitive level. ${ }^{28}$ Moreover, as discussed above, maximum RPM can have a particular procompetitive effect in conjunction with exclusive dealer territories by reining in the exploitation of market power. Posner also reviewed the discrepancy between Sylvania and Albrecht identified in his own academic writing, ${ }^{29}$

24 Posner, 45 U Chi L Rev at 12 (cited in note 9).

25 By this point, Posner had written a third paper proposing per se legality for all intrabrand restraints. Richard A. Posner, The Next Step in the Antitrust Treatment of Restricted Distribution: Per Se Legality, 48 U Chi L Rev 6, 23 (1981).

26737 F2d 698 (7th Cir 1984).

27 Id at 706 .

28 Id at 706-07, citing Frank H. Easterbrook, Maximum Price Fixing, 48 U Chi L Rev 886, 890 n 20 (1981).

29 Id at 706 ("Now that assigning exclusive territories to dealers is lawful if reasonable, a manufacturer-imposed price ceiling intended to limit the power that exclusive territories give dealers to raise prices regardless of what other dealers in the manufacturer's product are charging may also be lawful in some cases."). 
although (characteristically) he did not cite that work in the opinion. ${ }^{30}$

These two arguments obviously did not provide an adequate basis for ignoring controlling Supreme Court precedent. Posner then turned to a third strategy that sidestepped Albrecht rather than directly confronting it. The vehicle for this shift was the antitrust injury doctrine.

Antitrust injury requires a private plaintiff seeking damages to show not only that its injury was caused by unlawful conduct but also that its injury was caused by that which makes the conduct unlawful. This hurdle to recovery was announced in Brunswick Corp $v$ Pueblo Bowl-O-Mat, Inc, ${ }^{31}$ a case decided a few months before Sylvania that initially received much less attention. The plaintiff alleged compensable harm caused by a merger of competing bowling centers. Its theory of harm was that absent the merger, some of the bowling centers would have gone out of business, thereby benefiting the plaintiff. In essence, plaintiff complained about an increase in competition rather than a decrease. ${ }^{32}$

The Court reviewed the statutory provision providing a right of recovery to "person[s] . . injured ... by reason of" an antitrust violation. ${ }^{33}$ The Court decided that although the plaintiff might literally be a "person injured by reason of" unlawful conduct, damages were unavailable because the plaintiff's loss did not occur "by reason of" that which made the acquisitions unlawful." ${ }_{34}$ Even if plaintiff suffered injury, it did not suffer "antitrust injury, which is to say injury of the type the antitrust laws were intended to prevent and that flows from that which makes defendants' acts unlawful." 35

Antitrust injury is sometimes framed as being about the "wrong plaintiff": yes, the conduct complained of may well be anticompetitive, but this plaintiff does not have an injury that flows from the anticompetitive nature of the conduct. However,

30 Instead, the opinion cited Robert Pitofsky for this point. See Robert Pitofsky, The Sylvania Case: Antitrust Analysis of Non-Price Vertical Restrictions, 78 Colum L Rev 1, 16 n 59 (1978).

31429 US 477 (1977).

32 See id at $480-81$.

3315 USC $\S 15$ (codifying $\S 4$ of the Clayton Act, which provides a cause of action to "any person who shall be injured in his business or property by reason of anything forbidden in the antitrust laws").

34 Brunswick, 429 US at 488 (emphasis added).

35 Id at 489 (emphasis in original). 
it can equally be understood as denying recovery for the wrong kind of harm.

In Jack Walters, Posner explained that "[t]here is nothing esoteric about the Brunswick rule. It is the application to antitrust law of venerable principles of tort causation illustrated by Gorris v Scott." ${ }^{36}$ Gorris is a nineteenth-century English tort case that Posner had examined in academic work with Bill Landes the year before. ${ }^{37}$ Posner described the case as follows:

The plaintiff's animals, which were being transported on the deck of the defendant's ship, were washed overboard in a storm. They would have been saved if the deck had been penned, as required by statute. But since the purpose of the statute was to prevent contagion, not drowning, the defendant was not liable. ${ }^{38}$

The Gorris analogy brings together two common features of Posner opinions: an effort to demystify specialized law by connecting it back to general principles and a love of vivid facts. He found reason to cite Gorris in ten subsequent opinions, about half as often as Raffles $v$ Wichelhaus. ${ }^{39}$

Applying the Brunswick/Gorris rule to the claim at hand, Posner concluded that the plaintiff's only harm came from competitors' lower prices, which was hardly the sort of harm that antitrust is concerned about. ${ }^{40}$ And in a further twist of the knife, Posner found plaintiff's case even weaker than in Gorris. There, "[t]he loss of the animals was a pure social cost, while the loss to [plaintiff] from lawful price competition was a gain to consumers." 41

So far as I know, this was Posner's first discussion of antitrust injury. I am not aware of his having previously discussed the issue in his own academic work. Posner may have been encouraged to adopt an antitrust injury approach in Jack Walters

\footnotetext{
36 Jack Walters, 737 F2d at 708-09 (citation omitted).

37 See William M. Landes and Richard A. Posner, Causation in Tort Law: An Economic Approach, 12 J Legal Stud 109, 130-31 (1983).

38 Jack Walters, $737 \mathrm{~F} 2 \mathrm{~d}$ at 709.

39159 Eng Rep 375 (Ex 1864). See William Domnarski, Richard Posner 111 (Oxford 2016) (reporting that Gorris is Posner's second most frequently cited nineteenth-century English opinion after Raffles).

40 Jack Walters, 737 F2d at 709 ("[T] $]$ he only harm to Walters came from the fact that competing dealers (or Morton itself) would lower their prices to consumers if Walters did not.").

41 Id.
} 
by an academic article, authored by Bill Page and cited in the opinion, that itself bears a strong Chicago imprint. ${ }^{42}$

Jack Walters illustrates the real potential of antitrust injury. A defendant or court can sidestep and neutralize the effect of liability while leaving the formal scope of liability undisturbed. This tool is particularly powerful when the legal case for liability is ironclad, yet the economic theory of harm is incoherent given the goals of the statute. From this perspective, Albrecht was a perfect target. A further consequence is to place pressure on liability over time, as judges give voice to the analytical problems with overbroad liability.

Posner's opinion gave a "jolt" to the antitrust bar. ${ }^{43}$ Commentators recognized it as an indirect attack on Albrecht. ${ }^{44}$ The Ninth Circuit, in a maximum RPM case called USA Petroleum Co $v$ Atlantic Richfield Co $(A R C O),{ }^{45}$ staked out a flatly contrary view to Jack Walters, and the Supreme Court granted certiorari. ${ }^{46}$ At oral argument, respondent characterized the Ninth Circuit's disagreement with Judge Posner as follows:

42 See id, citing William H. Page, Antitrust Damages and Economic Efficiency: An Approach to Antitrust Injury, 47 U Chi L Rev 467, 491 (1980). Page was a Chicago LLM student, and Posner commented on the paper in draft. The subject was apparently first proposed to Page by another Chicago colleague, Kenneth Dam, who suggested that "[m]aybe the principle [of Brunswick] can be extended. You may not be able to do much about the substantive law, but you might be able to affect the penalties." John E. Lopatka and William H. Page, Brunswick at 25: Antitrust Injury and the Evolution of Antitrust Law, 17 Antitrust 20, 20 (Fall 2002).

43 Donald J. Polden, Antitrust Standing and the Rule against Resale Price Maintenance, 37 Cleve St L Rev 179, 217 (1989) ("The antitrust bar received a jolt. . . .").

44 For example, Herbert Hovenkamp wrote:

[A]ny rule requiring a plaintiff to show that it has been injured by the anticompetitive consequences of maximum resale price maintenance is a rule of nonrecovery. I cannot escape the conclusion that Judge Posner-growing impatient with Congress's or the Supreme Court's refusal to overrule Albrecht-has decided to undertake that task on his own.

Herbert Hovenkamp, Chicago and Its Alternatives, 1986 Duke L J 1014, 1026. See also Mark E. Roszkowski, Vertical Maximum Price Fixing: In Defense of Albrecht, 23 Loyola U Chi L J 209, 212 (1992) (criticizing Jack Walters as an illustration of the claim that the Seventh Circuit, "unable directly to overrule Albrecht," had narrowed it by means of the antitrust injury doctrine); Polden, 37 Cleve St L Rev at 219-20 (cited in noted 43) (criticizing the Seventh Circuit view, illustrated by Jack Walters, as unduly elevating allocative efficiency and resulting in a rule of nonrecovery for certain antitrust violations); John J. Flynn, The "Is" and "Ought" of Vertical Restraints after Monsanto Co. v. Spray-Rite Service Corp., 71 Cornell L Rev 1095, 1118-19 (1986) (broadly criticizing maximum RPM analysis in Jack Walters).

45859 F2d 687 (9th Cir 1988), revd, 495 US 328 (1990).

46 Id at 697 \& n 15; 490 US 1097 (1989) (granting certiorari). 
I can't substitute myself for Judges Reinhardt and Nelson, but I'll tell you what I think is [in] their head. I think that the Seventh Circuit in Jack Walter[s] and [another case] said that there can be good price fixing. I [was] shocked by Judge Posner's statement ... that price fixing can be procompetitive; [that] it's a legitimate competitive weapon. ${ }^{47}$

The Court's $A R C O$ opinion, written by Justice William Brennan, vindicated Judge Posner's position. ${ }^{48}$ The court concluded that even for a per se violation such as maximum RPM (Albrecht had not yet been overruled), antitrust injury must be shown, given its distinct purpose: "It ensures that the harm claimed by the plaintiff corresponds to the rationale for finding a violation of the antitrust laws in the first place, and it prevents losses that stem from competition from supporting suits by private plaintiffs for either damages or equitable relief." 49

Jack Walters and ARCO had several effects. First, by undercutting the availability of damages, they reduced the attractiveness of maximum RPM cases to private plaintiffs. Government enforcers do not need to show antitrust injury, ${ }^{50}$ and hence their incentive to bring maximum RPM cases was unaffected. However, enforcers' interest in bringing these cases was quite low. Thus, in practice these cases came close to a stealth overruling of Albrecht.

Second, Jack Walters and ARCO paved the way for the formal overruling of Albrecht. ${ }^{51}$ In Khan $v$ State Oil Co, ${ }^{52}$ the Seventh Circuit reviewed a form of maximum RPM imposed by a gasoline supplier on its customer, a gas station.53 Under the contract, the station paid the supplier a wholesale price that was 3.25 cents less than the station's "suggested" retail price. Any proceeds above the suggested price were rebated to the supplier. ${ }^{54}$

\footnotetext{
47 Transcript of Oral Argument, Atlantic Richfield Co v USA Petroleum Co, No 881668, *45-46 (US filed Dec 5, 1989), archived at http://perma.cc/V65G-8Q79.

48 Atlantic Richfield Co $v$ USA Petroleum Co, 495 US 328, 345-46 (1990).

49 Id at 342.

50 See California v American Stores Co, 495 US 271, 295-96 (1990) (describing the greater burden of private litigants compared to government enforcers).

51 For a critical view of the role of antitrust injury, see Jonathan M. Jacobson and Tracy Greer, Twenty-One Years of Antitrust Injury: Down the Alley with Brunswick v. Pueblo Bowl-O-Mat, 66 Antitrust L J 273, 303 (1998) ("By basing its decision on antitrust injury grounds, the $A R C O$ Court unnecessarily delayed the demise of Albrecht seven more years, giving the precedent additional time to do more damage in the lower courts.").

5293 F3d 1358 (7th Cir 1996).

53 Id at 1359-60.

54 Id at 1360.
} 
As in Jack Walters, Posner once again discussed how maximum RPM can serve as a brake on the exercise of dealer market power ${ }^{55}$ and noted the incongruity between Sylvania's permissiveness toward dealer territories and the unbending Albrecht rule. ${ }^{56}$ Moreover, in the wake of $A R C O$, Posner had a new tension to point out-that between $A R C O$ and Albrecht. ${ }^{57}$ However, as with Jack Walters, these arguments alone were not enough to justify ignoring Albrecht as controlling precedent. Posner continued to resist the strategy, adopted (for example) by Judge Bork, of declaring a per se precedent effectively overruled in advance of the Supreme Court taking that step. ${ }^{58}$

In contrast to Jack Walters, Posner concluded that the third strategy - to deny the existence of plaintiff's antitrust injurywas not available because, on his reading of the reasoning in $A R C O$, the Court apparently regarded maximum RPM as (sometimes) producing antitrust injury after all.59 Ultimately, Posner declared Albrecht to be "unsound when decided," lamented its "increasingly wobbly, moth-eaten foundations,"60 and held that Albrecht controlled the facts of the case, effectively inviting the Supreme Court to reverse him. In State Oil Co $v$ Khan, ${ }^{61}$ the Court unanimously obliged, overruling Albrecht while adopting

55 Id at 1362 ("As for maximum resale price fixing, unless the supplier is a monopsonist he cannot squeeze his dealers' margins below a competitive level. . . A supplier might, however, fix a maximum resale price in order to prevent his dealers from exploiting a monopoly position.").

56 State Oil, 93 F3d at 1363.

57 Id ("We have considerable sympathy with the argument that Albrecht is inconsistent with the cases that establish the requirement of proving antitrust injury. In fact, we think the argument is right and that it may well portend the doom of Albrecht.").

58 See Rothery Storage \& Van Co v Atlas Van Lines, Inc, 792 F2d 210, 229 (DC Cir 1986) (concluding that two Supreme Court per se precedents, United States v Sealy Corp, 388 US 350 (1967), and United States v Topco Associates, 405 US 596 (1972), are "effectively overruled" by other rule-of-reason precedents).

59 In $A R C O$, the plaintiff was a competitor of the dealers subject to maximum RPM. Posner explained that the ARCO Court had distinguished Albrecht on the ground that those dealers, rather than a competitor, were the "intended beneficiaries of Albrecht." State Oil, 93 F3d at 1364, discussing ARCO, 495 US at 336-37. From this distinction, Posner drew the implication that the Court regarded such dealers as having antitrust injury after all, apparently contrary to the Seventh Circuit's conclusion on this point in Jack Walters.

60 State Oil, 93 F3d at 1363. For example, unlike other vertical restraints, maximum RPM does not interfere with price cutting, and (as discussed in the text) helps to reduce the potential anticompetitive effect of other vertical restraints by controlling the harmful effects of dealer territories.

61522 US 3 (1997). 
much of the reasoning set out in Posner's two maximum RPM opinions. ${ }^{62}$

\section{ANTITRUST INJURY BEYOND MAXIMUM RPM}

The potential use of antitrust injury as a means to undermine the rigid imposition of liability is not limited to maximum RPM. Consider minimum RPM, which after State Oil Co v Khan was the last remaining vertical intrabrand restraint still subject to per se liability. Several Seventh Circuit opinions chipped away at RPM on antitrust injury grounds. ${ }^{63}$ For example, in Isaksen $v$ Vermont Castings, Inc, ${ }^{64}$ Posner considered a lostprofits claim from a dealer forced to "knuckl[e] under" to a manufacturer's imposition of RPM. ${ }^{65}$ Such a dealer could be expected to claim that it had been forced to charge an unprofitably high price.

Here, the antitrust injury objection was not that the challenged restraint was actually procompetitive. The issue was subtle: that prior to being forced into compliance, the dealer's profits might have resulted, in part, from undercutting competing RPM-compliant dealers.66 Posner wrote: "The prevention of free riding is not, as yet anyway, a defense to a charge of resale price maintenance; but neither is being prevented from taking a free ride on another dealer's efforts a form of antitrust injury compensable by a damage award."67 Put another way, dealer profits inflated by the other dealers' compliance with the RPM scheme offered an improper benchmark for calculating damages. ${ }^{68}$

62 See id at 20-22.

63 See Isaksen v Vermont Castings, Inc, 825 F2d 1158, 1165 (7th Cir 1987); Local Beauty Supply, Inc v Lamaur Inc, 787 F2d 1197, 1201-03 (7th Cir 1986).

64825 F2d 1158 (7th Cir 1987).

65 Id at 1162.

66 The same issue had arisen in another case. In Local Beauty Supply, a dealer complained that due to termination, it had been denied the opportunity to undercut and free-ride on the investments of RPM-compliant dealers. In other words, "plaintiffs' ... profits were attributable to the violation of which they complained." Local Beauty Supply, $787 \mathrm{~F} 2 \mathrm{~d}$ at 1203. The increased competition from ending RPM would hurt rather than help the plaintiff.

67 Isaksen, 825 F2d at 1165, citing Local Beauty Supply, 787 F2d at 1202.

68 Moreover, because the jury had no basis for distinguishing which part of the damages claim was based on an improper benchmark, the court concluded that the damages part of the case must be retried. Isaksen, $825 \mathrm{~F} 2 \mathrm{~d}$ at 1165. 
Other defendants used antitrust injury to launch a frontal attack on RPM. ${ }^{69}$ For example, in PSKS, Inc v Leegin Creative Leather Products, Inc, ${ }^{70}$ defendants sought to introduce the testimony of an economic expert to show "that consumers have not been harmed by Leegin's conduct [and] that the arrangement promotes interbrand competition." 71 The district court, unwilling to grant defendants an indirect route to nullifying the per se rule, rejected this approach. ${ }^{72}$ Ultimately, the case reached the Supreme Court as Leegin Creative Leather Products, Inc $v$ PSKS, Inc, ${ }^{73}$ in which the Supreme Court duly overruled its precedent, switching the test from per se liability to the rule of reason. ${ }^{74}$

Beyond its continuing application in "wrong plaintiff" cases such as competitors complaining about a merger or horizontal agreement, ${ }^{75}$ the antitrust injury strategy has potential application in any context in which arguably procompetitive conduct is subject to per se liability. With the continuing decline of per se liability in antitrust law, that domain is shrinking. A remaining example is tying cases, in which a modified per se approach applies. ${ }^{76}$ Defendants in these cases sometimes argue that even if liability attaches to the conduct, their conditional sale results in

69 Some commentators perceived such a goal in Isaksen itself. See Roger D. Blair and Jeffrey L. Harrison, Rethinking Antitrust Injury, 42 Vand L Rev 1539, 1557 (1989) ("Although the Seventh Circuit opinions [in Isaksen and Local Beauty Supply] are expressed in terms of antitrust injury, they also can be seen as having the substantive impact of making resale price maintenance effectively per se lawful.”).

702004 WL 5374523 (ED Tex).

71 Id at *1.

72 Id. See also PSKS, Inc v Leegin Creative Leather Prods, 2004 WL 5254322, *1-2 (ED Tex) (denying defendant's motion for a new trial and repeating the court's understanding that the defendant offered an indirect strategy for attacking the per se classification for RPM). The Fifth Circuit affirmed. PSKS, Inc v Leegin Creative Leather Prods, 171 Fed Appx 464, 467-68 (5th Cir 2006) (concluding that plaintiff established antitrust injury).

73551 US 877 (2007).

74 Id at 882 .

75 For example, in Hammes $v$ AAMCO Transmissions, Inc, 33 F3d 774 (7th Cir 1994), a dealer complained of exclusion from an advertising pool of other dealers. Defendants argued that the plaintiff had failed to allege antitrust injury. Posner agreed that a mere deprivation of cartel profits would not be compensable harm but had a different take on the complaint. Perhaps the plaintiff had wanted to undersell the dealers, he reasoned, and exclusion from the advertising pool was punishment. Posner concluded that this type of injury would indeed be compensable, and at the dismissal stage, it could not yet be said whether this was plaintiff's theory. Id at 782-83.

76 This approach was set out in Jefferson Parish Hospital District No $2 v$ Hyde, 466 US 2 (1984). 
no economically coherent harm or that the particular plaintiff has not alleged a compensable harm. ${ }^{77}$

Antitrust injury also furnished Posner with an analogy for use outside of antitrust law. For example, he deployed the antitrust injury approach while sitting as a district judge in a patent infringement case. In SmithKline Beecham Corp v Apotex Corp, ${ }^{78}$ Posner considered a claim of patent infringement brought by a branded drug maker against a would-be generic competitor. ${ }^{79}$ To simplify a complex set of facts, the patent at issue covered a particular crystalline structure of the drug's active ingredient. The generic made a different version of the active ingredient with a crystalline structure that was in the public domain. The brand presented evidence that the patented version would nevertheless be present in the generic's product in minute quantities, albeit as an unwanted byproduct that added nothing to the safety or efficacy of the drug.

Posner held a two-week bench trial and issued a lengthy opinion about two weeks later. ${ }^{80}$ As one of several grounds for denying injunctive relief to plaintiffs, Posner concluded that the plaintiff's injury was not of the kind that the law was intended to prevent. ${ }^{81}$ To buttress this conclusion, he pointed to antitrust injury, citing Jack Walters ${ }^{82}$ and "the colorful though very sad

77 See, for example, Midwest Gas Services, Inc v Indiana Gas Co, 317 F3d 703, 71213 (7th Cir 2003) (affirming dismissal of tying claims because claimed injury of lost profits resulted from conduct that was not anticompetitive); Todorov v DCH Healthcare Authority, 921 F2d 1438, 1453-54 (11th Cir 1991) (holding that, similar to Local Beauty Supply, no antitrust injury was present when the harm complained of was a lost opportunity to profit from the anticompetitive scheme); CBC Companies, Inc v Equifax, Inc, 561 F3d 569, 571-73 (6th Cir 2009) (dismissing a tying claim for lack of antitrust injury on the ground that allegations of harm in the tied product market were merely conclusory). But see Palmyra Park Hospital, Inc v Phoebe Putney Memorial Hospital, 604 F3d 1291, 1303 (11th Cir 2010) (concluding, in a tying case, that the plaintiff alleged antitrust injury resulting from its exclusion in tied product market).

78247 F Supp 2d 1011 (ND Ill 2003). I clerked for Judge Posner when this case was decided.

79 Id at 1013.

80 Id at 1011, 1013 (reporting that a bench trial was held from February 5 to February 21 and an opinion issued on March 3, 2003).

81 Id at 1048. See also Kaz Manufacturing Co $v$ Chesebrough-Ponds, Inc, 317 F2d 679, $680 \mathrm{n} 3$ (2d Cir 1963) ("[O]ne who constructs a patented wall safe but uses it only as an anchor for his boat would not be a patent infringer since such use would not be for the purpose of utilizing the teachings of the patent.").

82 SmithKline Beecham, $247 \mathrm{~F}$ Supp 2d at 1048, citing Jack Walters, $737 \mathrm{~F} 2 \mathrm{~d}$ at 708-09. 
old case" of Gorris $v$ Scott. ${ }^{83}$ Posner's approach has been echoed in recent academic calls to recognize "IP injury" and enforce IP law only when there is a violation of a core IP policy. ${ }^{84}$ The Federal Circuit never reached this argument in SmithKline Beecham, affirming on other grounds, ${ }^{85}$ and the real-world influence of this idea remains to be seen.

\section{HORIZONTAL RESTRAINTS}

In altering the law of vertical restraints, Posner's scholarship and judicial opinions have had a powerful and synergistic effect. Horizontal restraints provide a stark contrast. Here too, Posner staked out a distinctive position as an academic, but his opinions do not reflect similar progress toward judicial implementation. Instead, Posner ultimately became their leading judicial opponent.

During his first year as an academic, prior to joining the Chicago faculty, Posner considered what forms of collusion constitute an agreement-a "contract, combination ... or conspiracy, in restraint of trade" 86 - as required under $\S 1$ of the Sherman Act. Collusion, as I use the term here, refers to coordination by rivals as to some aspect of competition (for example, price or customers served) such that the firms achieve higher profits compared to a benchmark in which the parties did not coordinate in this manner. The benchmark is the equilibrium outcome if the parties met just once in the marketplace. The gains from collusion come from cooperation over time in refraining from competition, despite each firm's temptation to cheat on the arrangement.

Collusion can be either express or tacit. Tacit collusion refers to interdependent conduct 87 unaccompanied by communications between or among the parties. By contrast, express collusion is

83 SmithKline Beecham, 247 F Supp 2d at 1048 ("The principle is general and I cannot think of any reason why it should not apply to patent law.").

84 See, for example, Christina Bohannan and Herbert Hovenkamp, Creation without Restraint: Promoting Liberty and Rivalry in Innovation 50-55 (Oxford 2012).

85 SmithKline Beecham Corp v Apotex Corp, 403 F3d 1331, 1334 (Fed Cir 2005).

8615 USC $\S 1$.

87 See Louis Kaplow, Direct versus Communications-Based Prohibitions on Price Fixing, 3 J Legal Analysis 449, 451 (2011) (defining interdependence as a situation in which "firms refrain from price cutting because of an expectation of retaliation derived from a shared appreciation of their circumstances"). See also Donald F. Turner, The Definition of Agreement under the Sherman Act: Conscious Parallelism and Refusals to Deal, 75 Harv L Rev 655, 663 (1962) (discussing “conscious parallelism”). 
collusion that is not tacit-that is, reaching a collusive outcome with the assistance of communications. Communications facilitate collusion by helping to solve the economic challenges of coordination and prevention of cheating.

There is consensus that collusion supported by communication suffices to establish an agreement. To this end, a plaintiff might present direct evidence of agreement, such as a videotape of the conspirators caught in the act. In other cases, a plaintiff presents circumstantial evidence that indicates that the parties must have communicated, such as an unusual pattern of behavior that is hard to explain without communication. ${ }^{88}$ The question that interested Posner is whether purely tacit collusion is enough to satisfy the agreement requirement, either because such collusion is unlawful in its own right or because evidence of tacit collusion is probative of the existence of unobserved communications. The Supreme Court has not offered a clear answer to this question. ${ }^{89}$

Posner's 1969 paper on the subject staked out the position that tacit collusion does violate antitrust law. ${ }^{90}$ He emphasized that the structure of the problem of oligopolistic price elevation does not depend on "detectable acts of collusion." ${ }^{91}$ Price elevation is a voluntary rather than inevitable act. Posner acknowledged that identifying actionable price elevation would be difficult and, with respect to remedies, thought that the main challenge was to make sure that damages are high enough to achieve adequate deterrence given the difficulties of proving a case and the reluctance of courts to impose high penalties. ${ }^{92}$

As a judge, however, Posner made little effort to nudge the law toward an explicit recognition of liability for tacit collusion. His comments on the subject were notably circumspect. For example, in In re High Fructose Corn Syrup Antitrust Litigation, ${ }^{93}$ Posner wrote that "it is generally believed, and the plaintiffs

88 See, for example, Interstate Circuit, Inc $v$ United States, 306 US 208, 221 (1939).

89 For perspectives on the case law, see Louis Kaplow, Competition Policy and Price Fixing 69-92 (Princeton 2013); Keith N. Hylton, Oligopoly Pricing and Richard Posner, 18 Antitrust Source 1, 10-13 (Oct 2018).

90 See generally Richard A. Posner, Oligopoly and the Antitrust Laws: A Suggested Approach, 21 Stan L Rev 1562 (1969). This work was also incorporated in Posner's antitrust book. Posner, Antitrust Law: An Economic Perspective at 47 (cited in note 6).

91 Posner, 21 Stan L Rev at 1562 (cited in note 90). See also id at 1575 ("There is ... no vital difference between formal cartels and tacit collusive arrangements; the latter are simply easier to conceal.”).

92 Id at 1590-91.

93295 F3d 651 (7th Cir 2002). 
implicitly accept, that an express, manifested agreement, and thus an agreement involving actual, verbalized communication, must be proved in order for a price-fixing conspiracy to be actionable under the Sherman Act." ${ }_{44}$ This statement left open the possibility of a broader definition without endorsing it. In JTC Petroleum v Piasa Motor Fuels, ${ }^{95}$ Posner went a bit further, musing that when "oligopolistic interdependence" could be shown, a plaintiff could establish the existence of "a combination or a (tacit) conspiracy." 96

Around 2015, Posner took a sharp turn against his previous academic views. The first evidence was a review of Louis Kaplow's book about horizontal agreement and price fixing. ${ }^{97}$ Kaplow's book offers a sophisticated attack on a conception of agreement that is limited to express collusion. ${ }^{98}$ In the review, Posner repudiated his previous view that tacit collusion or mere interdependence is actionable. ${ }^{99} \mathrm{He}$ despaired that efforts to remediate interdependent pricing would face insuperable practical difficulties (an issue that Posner had acknowledged even in the 1960s). In particular, an injunction would be futile: How could a court implement or a firm respond to the requirement that a firm instead charge a more competitive price, or cease taking its competitor's prices into account? 100

This change of heart found its way into Seventh Circuit jurisprudence in Posner's 2015 opinion in In re Text Messaging Antitrust Litigation. ${ }^{101}$ Plaintiffs had alleged a conspiracy by four wireless carriers to fix the price of text messages. ${ }^{102}$ At the dismissal stage, the court (in an opinion also written by Posner)

94 Id at 654.

95190 F3d 775 (7th Cir 1999).

96 Id at 780. At the same time, Judge Posner declined to recognize a shared monopoly theory under $\S 2$, by which he meant collective liability without any showing of agreement among the excluders. Id.

97 See generally Richard A. Posner, Book Review, Review of Kaplow, Competition Policy and Price Fixing, 79 Antitrust L J 761 (2014).

98 See Kaplow, Competition Policy and Price Fixing at 387-97 (cited in note 89).

99 Posner, 79 Antitrust L J at 763 (cited in note 97).

100 Id at 764, 767. Here, Posner's view echoed those made by his opponent, Don Turner, in the 1960s. See Turner, 75 Harv L Rev at 669 (cited in note 87) ("[S]uch an injunction, read literally, appears to demand such irrational behavior that full compliance would be virtually impossible.").

101782 F3d 867 (7th Cir 2015).

102 The claims involved "per use" message pricing, as opposed to a monthly charge for a certain number (often unlimited) of messages. Plaintiffs alleged that the four defendants, in a series of ten steps from 2005 to 2008, raised the price of per-use texts from as low as two cents to twenty cents. Id at 875 . 
had allowed the case to proceed. ${ }^{103}$ The 2015 opinion reviewed the district court's grant of summary judgment to defendants after discovery.

Here, Posner bluntly stated that "[e]xpress collusion violates antitrust law; tacit collusion does not."104 Posner concluded that evidence of a market structure conducive to collusion and of noncompetitive market performance were insufficient because they did not clearly point toward express collusion. ${ }^{105}$ According to Keith Hylton, Posner's opinion is the first at the appellate level to "so clearly" state that tacit collusion is insufficient to support a $\S 1$ violation. ${ }^{106}$

Text Messaging has influenced other courts ${ }^{107}$ and has begun to attract commentary. 108 To the extent that Posner's new view ultimately takes hold, it may be difficult to separate the influence of Posner the judge (in embracing this view) from Posner the commentator (in withdrawing as a prominent supporter of the contrary position).

\section{CONCLUSION}

The Jack Walters and Text Messaging opinions bookend an exceptional judicial career. In Jack Walters, one of Posner's first antitrust opinions, we see the judge pressing hard to incorporate his academic views into antitrust law. In Text Messaging, one of Posner's last, we see the reverse: shaping Seventh Circuit law to expressly reject one of his signature academic positions. At the same time, Posner's disparate approach to these two areas of antitrust doctrine share an important point of commonality, one entirely in keeping with his iconoclastic approach to other areas of

103 In re Text Messaging Antitrust Litigation, 630 F3d 622, 628-29 (7th Cir 2010) (discussing Bell Atlantic Corp v Twombly, 550 US 544 (2007)).

104 Text Messaging, 782 F3d at 872.

105 Id at 879.

106 Hylton, 18 Antitrust Source at 3 (cited in note 89) ("As far as I am aware, [Text Messaging] is the first appellate court opinion to state such a position so clearly.").

107 See, for example, Valspar Corp v E.I. du Pont de Nemours \& Co, 873 F3d 185, 200 \& n 13 (3d Cir 2017) (citing Text Messaging for the proposition that acting in accordance with tacit understanding of how competitors will act is not actionable). See also Kleen Products LLC v Georgia-Pacific LLC, 910 F3d 927, 935 (7th Cir 2018) (similar).

108 See, for example, Douglas H. Ginsburg, Posner on Antitrust Remedies: The Good, the Bad, and the Very Ugly, 18 Antitrust Source 1, 7-9 \& n 47 (Oct 2018) (discussing Posner's changed view); Salil K. Mehra, Antitrust and the Robo-Seller: Competition in the Time of Algorithms, 100 Minn L Rev 1323, 1343 (2016) ("[T] he advent of the robo-seller shifts the balance between these arguments in the direction of Posner's half-century-old argument."). 
law. Whether the target is a Supreme Court case he had won just a few years previously or a long-held academic view, Posner has never been afraid to change his mind. 